\title{
ATTITUDES OF THE LOCAL RESIDENTS TOWARDS THE POSSIBILITIES OF ECOTURISM DEVELOPMENT IN THE AREA OF THE SPECIAL NATURE RESERVE “DELIBLATO SANDS”
}

\author{
Marija Zeljković ${ }^{* 1}$ \\ " Master's student at the University of Belgrade - Faculty of Geography, Belgrade
}

\begin{abstract}
Ecotourism is a form of tourism, increasingly developed within protected natural areas due to its ability to minimize negative impacts on the environment and contribute to the preservation and improvement of natural values. In addition to natural potentials, scientific literature emphasizes the importance of the involvement of the local community in ecotourism development, through which multiple socioeconomic benefits for the local population are obtained. Deliblato Sands is an area protected as a Special Nature Reserve, thanks to its specific morphological features, rich biodiversity, rare species and exceptional landscape values. This research examines the attitudes of the inhabitants of the municipalities of Vrsac, Bela Crkva, Kovin, Alibunar and Pancevo, on whose territories the borders of SNR «Deliblato Sands» are located, about the development of ecotourism in Deliblato Sands, its impact on the environment and community and readiness of local population for direct involvement in ecotourism development. The attitudes of 339 respondents were collected through an online survey, and the results of the research were presented by descriptive analysis. It was determined that the inhabitants of municipalities in South Banat have a positive attitude towards the development of ecotourism in the area of SNR «Deliblato Sands», and a proactive approach to direct involvement in further ecotourism development of this area.
\end{abstract}

Keywords: ecotourism, Deliblato Sands, attitudes, local population.

1 Corresponding author: M. Zeljković, Belgrade; e-mail: maki.zeljkovic96@gmail.com 


\section{Introduction}

The term ecotourism appeared in the early 1980s. It was defined by CeballosLascurain as: "traveling to relatively undisturbed or uncontaminated natural areas with the specific object of studying, admiring and enjoying the scenery and its wild plants and animals, as well as any existing cultural manifestations (both past and present) found in these areas" (Ceballos-Lascurain, 1987). A visit to relatively untainted and unspoiled natural areas, where the main travel motive is contact with natural resources and interest in the natural features of the visited area is emphasized as an important characteristic of ecotourism (Fennel, 2015). When natural values are highlighted as the primary tourist resource of a certain area, it is necessary to focus on the development of those activities that will not disturb the environment (Đurđić, Stojković and Belij, 2019) but also to encourage the expansion of ecological awareness and ecological behavior towards natural values in the environment (Петровић и Шкрбић, 2016). Also, the emphasis has to be on the involving of the local population in ecotourism development and achieving the economic effects through it (Fennell, 2015). Perceiving ecotourism as an additional source of income, local people are motivated to value natural areas in their environment and contribute to their protection. Also, local culture attracts visitors, so its preservation and presentation are other reasons for involving the population in the development of ecotourism (Ghazali and Sirat, 2011). The community participation in tourism development enables locals to direct the type of development and control its influences (Diamantis, 2010). Some authors state that the population's interests in getting involved in tourism development and interaction with visitors are conditioned by their perception of the benefits they will achieve this way. If they are aware that tourism is driving positive changes, they will be more willing to participate directly in its development. Otherwise, they will probably have a negative attitude towards tourism development, believing that it will bring more costs than benefits (Nunkoo and Ramkissoon, 2011; Nunkoo, Ramkissoon and Gursoy, 2013; Nunkoo and So, 2015; Sharpley, 2014).

Recognition of the potentials for ecotourism development in Serbia is constantly growing, which provides the opportunity to revitalize rural areas and achieve multiple benefits for the population while contributing to the improvement and protection of natural areas (Jovanović et al, 2019). In Serbia, ecotourism is in the initial phase of development, and thanks to well-preserved, authentic and rare natural values, it is characterized by significant development potential, whose use would contribute to the formation of a new tourist offer and image of Serbia as a destination rich in unique natural attractions (Đurđić, 2017).

This paper will focus on the Deliblato Sands, a protected area in the territory of Southern Banat with great potential for ecotourism development. Deliblato 
Sands is protected as a Special Nature Reserve on the area of 34,829 ha, and is the largest protected area of this type in Serbia (Pokrajinski zavod za zaštitu prirode, n.d.). It aims to explore the possibilities of ecotourism development in the area of SNR "Deliblato Sands" and assess the potential of the local population as a subject in its development. Furthermore, the paper will examine the competitiveness of this destination, Special Nature Reserve "Kraljevac" and the Landscape of Outstanding Features "Karas-Nera", which are spatially and functionally connected with SNR "Deliblato Sands" and have similar ecological and geographical features. Results obtained by surveying residents from the municipalities of Vrsac, Bela Crkva, Kovin, Alibunar and Pancevo, on whose territories the borders of protected areas considered in this research are located, will present residents' information about the potentials of Deliblato Sands for tourism development, their attitudes about ecotourism, awareness of ecotourism impacts on the socio-economic development of the municipality in which they live, as well as the locals' willingness for direct involvement in the ecotourism development on the territory of Deliblato Sands.

\section{Previous researches}

Numerous researches related to the involvement of local communities in the development of tourism in natural and protected areas of Serbia and residents' attitudes towards tourism development have been conducted so far (Brankov, Jovičić and Milijašević, 2015; Vujko, Petrović, Gostović, Radovanović and Vuković, 2018; Pajvančić and Markov, 2011; Пантелић, Стаменковић и Пурић-Самарџија, 2012).

Group of authors (Brankov et al., 2015) examined the attitudes of the local community towards sustainable tourism development in the Djerdap National Park and its effects on the population from the municipalities of Golubac, Majdanpek and Kladovo. It was found that tourism development creates the possibility of generating new jobs for the community, contributes to the preservation of local culture, but also leads to higher prices of goods and services. Respondents showed a positive attitude towards sustainable tourism development and did not perceive it as a threat to the environment and common community activities. However, it was noticed that the local population is not well informed about sustainable tourism.

Vujko et al. (2018) studied Subotica residents' perception of the ecotourism development potentials in protected natural landscapes in Subotica surroundings. The survey encompassed four protected areas: Nature Park "Palić", the Special Nature Reserve "Ludaško Lake", the Special Nature Reserve "Selevenjske pustare" and the Landscape of Outstanding Features "Subotica Sands". The re- 
sults showed high awareness of the positive effects on the local community, as a consequence of nature-based tourism development, while economic effects are perceived as the most significant.

The research conducted among the population of urban settlements on the banks of the Danube in Vojvodina, aimed to assess the potential of the local population as a subject in the development of ecotourism. The results showed awareness of environmental problems and a positive attitude towards ecotourism development, but the absence of direct participation in it. It was also noted that women and residents of lower social status are more interested in contributing to ecotourism development, through which they can potentially generate additional income. (Pajvančić and Markov, 2011).

Пантелић et al. (2012) have already researched the possibility of ecotourism development in the area of SNR "Deliblato Sands". By examining inhabitants of Vrsac municipality, scientists found out that the local population is informed about activities in ecotourism and interested in participation in ecotourism trips, which are perceived as a generator of positive effects on the local community and environment, with special emphasis on economic benefits.

In contrast to the paper that dealt with the possibilities of ecotourism development in the area of SNR "Deliblato Sands" examining exclusively residents of the municipality of Vrsac, this paper has a more comprehensive approach, evident through analyzing the attitudes of residents of five municipalities within the protected area. Furthermore, apart from a willingness to participate in ecotourism trips, this paper examines residents' ambition to be involved in ecotourism development.

\section{Field of study}

Deliblato Sands (or Big Sands, Banat Sands) is located on the territory of five South Banat municipalities - Vrsac, Bela Crkva, Kovin, Alibunar and Pancevo. It covers an area of 34,829 ha (Pokrajinski zavod za zaštitu prirode, n.d.) and is surrounded by Banat loess plain. Deliblato Sands is the largest sandy terrain in Europe, created in the late Middle and Upper Pleistocene (Пантелић и др., 2012). The most common theory about the formation of Deliblato Sands is that the Danube river deposited clayey and sandy material, which was dispersed by wind Kosava and deposited at places of weakening its transport power (Menković, 2013).

The specificity of this area is reflected in the relief that is unique in Europe, rich flora and fauna and culture of multiethnic communities which represent the basis for equal evaluation of geodiversity, biodiversity and cultural values 
for tourism development (Belij, Đurđić and Stojković, 2018). The relief is represented by dunes and slacks between them. They create dynamic and attractive landscapes, especially in the northern and northwestern parts where the height difference between dunes and slacks is up to $30 \mathrm{~m}$ (Пантелић и др., 2012). The curiosity of this area are also thermal and mineral springs whose potentials are still not sufficiently used (Bubalo-Živković et al, 2018). The vegetation of the Deliblato Sands is lush and diverse and is characterized by steppe, sandstone, forest and swamp biomes (Бранков, 2010). Afforestation on the territory of the Deliblato Sands caused improvement of microclimatic conditions, prevention of aeolian erosion and development of the pedogenetic process. (Sedlak, 2019). This area is a habitat for about 40 rare plant and 200 rare animal species, protected by the strictest protection regime (Бранков, 2010). The fauna of Deliblato Sands is mostly famous for ornithofauna and the presence of some of the most endangered bird species in Serbia (Bee-eaters - Merops apiaster, Banat falcon Falco cherrug, Lesser spotted eagle - Clanga pomarina). As a consequence of that, this area is recognized as an Important Bird Area (IBA).

Deliblato Sands represents a Special Nature Reserve. At the national level, it has first-category protection status, denoting a natural asset of exceptional value (Бранков, 2010). It is also recognized as one of the most important centers of biodiversity in Europe (Trišić, 2019). Within the Deliblato Sands, three zones with different protection regimes have been established. The development of tourism based on ecological forms that do not disturb natural values is possible in zones II and III (Ковачев, Ромелић, Пивац и Лукић, 2014).

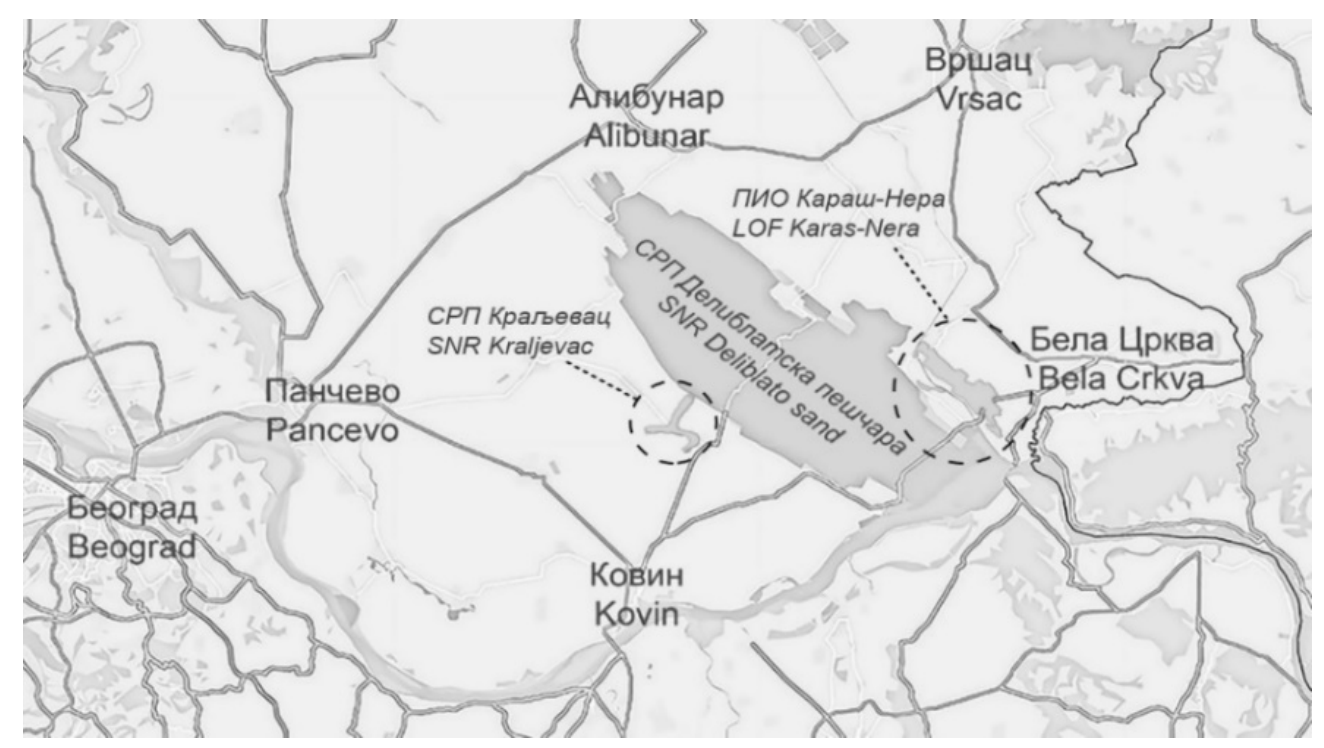

Figure 1. Geographical position of study area 
Krejić and Plećić (2014) explain that Deliblato Sands is an area suitable for the development of specific tourism types. Tourist offer has to be based on sports activities, hiking, volunteer engagements, excursions, bird watching, animal photography, educational workshops, collecting plants and cycling, in order to achieve sustainable development, a prosperity of the local population, nature conservation and satisfaction of visitors' and stakeholders' needs.

Due to the spatial proximity, connection with the territory of Deliblato Sands and similar resource base for tourism development, protected areas Special Nature Reserve "Kraljevac" and Landscape of Outstanding Features "KarasNera" have the potential to integrate offer with SNR "Deliblato Sands" and become the stronghold for the development of ecotourism in the South Banat region.

Since 2009, SNR “Kraljevac" represents a protected area, extending on 264.3 ha in South Banat on the territory of the municipality of Kovin (Udruženje sportskih ribolovaca „Deliblatsko jezero", 2015). It is a natural asset of exceptional importance and a part of the ecological network Natura2000. It has been declared as a Special Nature Reserve due to its authentic natural features and rich biodiversity. It consists of three parts: the pasture Spasovina, Obzovik valley and part of the watercourse Kraljevac. Through the Obzovik valley, it is connected and permeated with the SNR “Deliblato Sands" (Petrović, 2014).

LOF "Karas-Nera" is a unique landscape and biodiversity area located between the ecological corridors of the Danube, Nera and Karas rivers, next to the SNR “Deliblato Sands". Since 2015, it has been protected, covering 1541 ha. The most important resources for tourism development are hydrological values and diverse wildlife. This landscape consists of three parts: "Karas", "Nera" and "Mali pesak". It is a protected area of provincial importance, and according to the IUCN categorization, it belongs to the IV category (Habitat/Species Management Area). Parts of this area (Mali pesak and meanders of the Karas River) are recognized as an Important Bird Area, while the confluence of the Nera and the Danube river is part of the Ramsar site "Labudovo okno" (Покрајински секретаријат за урбанизам и заштиту животне средине, 2019).

Strengthening the complementarity of SNR "Deliblato Sands", SNR "Kraljevac" and LOF "Karas-Nera" through the joint promotion of similar natural features and ecosystems, would contribute to the creation of an integrated tourist offer based on environmentally responsible activities.

\section{Research metodology}

In order to examine the possibilities of ecotourism development in the SNR "Deliblato Sands" and the potential of the local population as the subject in its 
development, an empirical approach was applied through an online survey distributed through social networks. The surveys were posted in the Facebook groups that bring together residents of the municipalities of Vrsac, Alibunar, Bela Crkva, Pancevo and Kovin. Data collection lasted for 15 days, from April 29, 2020 to May 13, 2020. The survey consisted of 24 closed-ended and 2 semiclosed questions. In closed-ended questions respondents chose the answer from several offered, while in semi-closed questions they also had the opportunity to write their answer. The first 5 questions were supposed to determine the level of information about the potentials of SNR "Deliblato Sands", SNR "Kraljevac" and LOF "Karas-Nera" for tourism development. The next 2 questions were focused on comparing the ecotourism potentials of these 3 areas and determining the competitiveness of these destinations. The next 13 questions were formulated in the form of statements. Respondents had the opportunity to agree or disagree with them by choosing the answer yes or no. Their goal was to obtain residents' attitudes towards the multiple impacts and benefits of ecotourism development in SNR "Deliblato Sands", as well as residents' previous contributions and readiness for direct participation in the ecotourism development. The last 6 questions were intended to determine the demographic characteristics.

\section{Research results and the analysis}

Program Excel was used for the statistical processing of the results. Demographic characteristics of the sample and research results were presented using descriptive analysis. The sample consisted of 339 respondents.

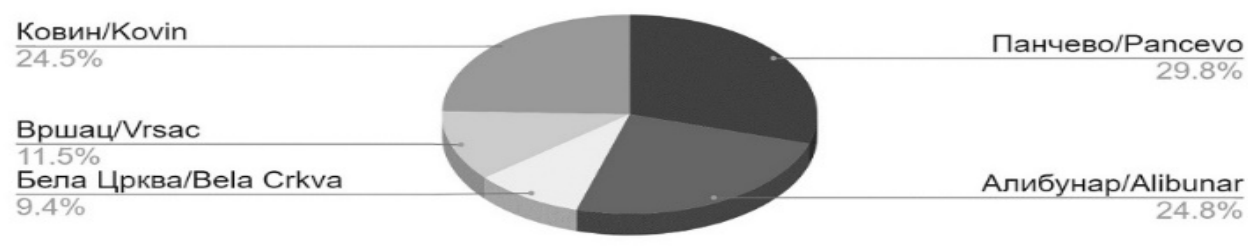

Figure 2. Distribution of respondents by administrative territories

The greatest interest in participating in the research was expressed by residents of the municipality of Pancevo, which is the municipality in the South Banat that has the largest number of inhabitants. On the other side, residents of Bela Crkva were the least interested in participating in the research. 
Table 1. Demographic characteristics of the sample

\begin{tabular}{|c|c|c|c|}
\hline \multicolumn{2}{|c|}{$\begin{array}{c}\text { Parameters of demographic segmentation of } \\
\text { respondents }\end{array}$} & $\begin{array}{l}\text { Number of } \\
\text { respondents }\end{array}$ & $\begin{array}{c}\text { Share in the total } \\
\text { sample }(\%)\end{array}$ \\
\hline Gender & $\begin{array}{c}\text { Man } \\
\text { Woman }\end{array}$ & $\begin{array}{l}142 \\
197\end{array}$ & $\begin{array}{l}41,9 \\
58,1\end{array}$ \\
\hline Age & $\begin{array}{l}\text { Up to } 20 \text { years } \\
\text { From } 21 \text { to } 40 \text { years } \\
\text { From } 41 \text { to } 60 \text { years } \\
\text { Over } 60 \text { years }\end{array}$ & $\begin{array}{c}7 \\
183 \\
123 \\
26\end{array}$ & $\begin{array}{c}2,1 \\
54 \\
36,3 \\
7,7\end{array}$ \\
\hline Acquired education & $\begin{array}{c}\text { Elementary school } \\
\text { High school } \\
\text { College } \\
\text { Faculty } \\
\text { Master studies } \\
\text { PhD studies }\end{array}$ & $\begin{array}{c}11 \\
142 \\
50 \\
91 \\
36 \\
9\end{array}$ & $\begin{array}{c}3,2 \\
41,9 \\
14,7 \\
26,8 \\
10,6 \\
2,7\end{array}$ \\
\hline Profession & $\begin{array}{c}\text { Pupil } \\
\text { Student } \\
\text { Employed } \\
\text { Unemployed } \\
\text { Retired }\end{array}$ & $\begin{array}{c}4 \\
27 \\
227 \\
55 \\
26 \\
\end{array}$ & $\begin{array}{c}1,2 \\
8 \\
67 \\
16,2 \\
7,7\end{array}$ \\
\hline Monthly income & $\begin{array}{c}\text { No income } \\
\text { Up to } 200 € \\
\text { From } 200 € \text { to } 500 € \\
\text { From } 500 € \text { to } 1000 € \\
\text { More than } 1000 €\end{array}$ & $\begin{array}{c}73 \\
26 \\
129 \\
88 \\
23\end{array}$ & $\begin{array}{c}21,5 \\
7,7 \\
38,1 \\
26 \\
6,8\end{array}$ \\
\hline
\end{tabular}

In the sample were dominant women (58.1\%), the population between 21 and 40 years $(54 \%)$ and respondents with high school education $(41.9 \%)$. The majority of respondents declared themselves as employed (67\%), with monthly income between $200 €$ and $500 €(38.1 \%)$.

The research established that the largest number of inhabitants of South Banat municipalities is partially $(32.7 \%)$ or poorly informed $(32.4 \%)$ about the potentials for tourism development in SNR "Deliblato Sands". Respondents are more informed about the tourism potentials in SNR "Deliblato Sands" then in SNR "Kraljevac" and LOF "Karas-Nera". As many as 46.9\% of respondents do not have any information about SNR "Kraljevac". Furthermore, the percentage of respondents who do not have any information or are poorly informed about the tourist potential of both SNR "Kraljevac" and LOF "Karas-Nera" exceeds $75 \%$. Although these two protected areas are close to Deliblato Sands and equally accessible to the local population, the level of information about them is extremely low. That can be related to the recent declaration of protection in SNR "Kraljevac" and LOF "Karas-Nera" and less promotion of these areas 
than SNR "Deliblato Sands". A correlation between the level of information on tourism potentials in the SNR "Deliblato Sands" and the level of respondents' education was found in the research results. It was noticed that the largest percentage of respondents who are poorly informed about tourism potentials in Deliblato Sands had finished high school, while the largest percentage of partially informed respondents had finished college, faculty and master's studies. To summarize, the higher the level of the respondents' education is, the more information they have about the natural values of the reserve. However, Figure 2 shows unexpected results related to the respondents who had completed primary school or PhD. The largest percentage of those with primary education are very informed, while among those who have doctorates is present an equal percentage of poorly and well informed. This irregularity can be associated with a small number of respondents who have completed primary school (11) and doctoral studies (9), and because of that, no relevant conclusions can be formed.

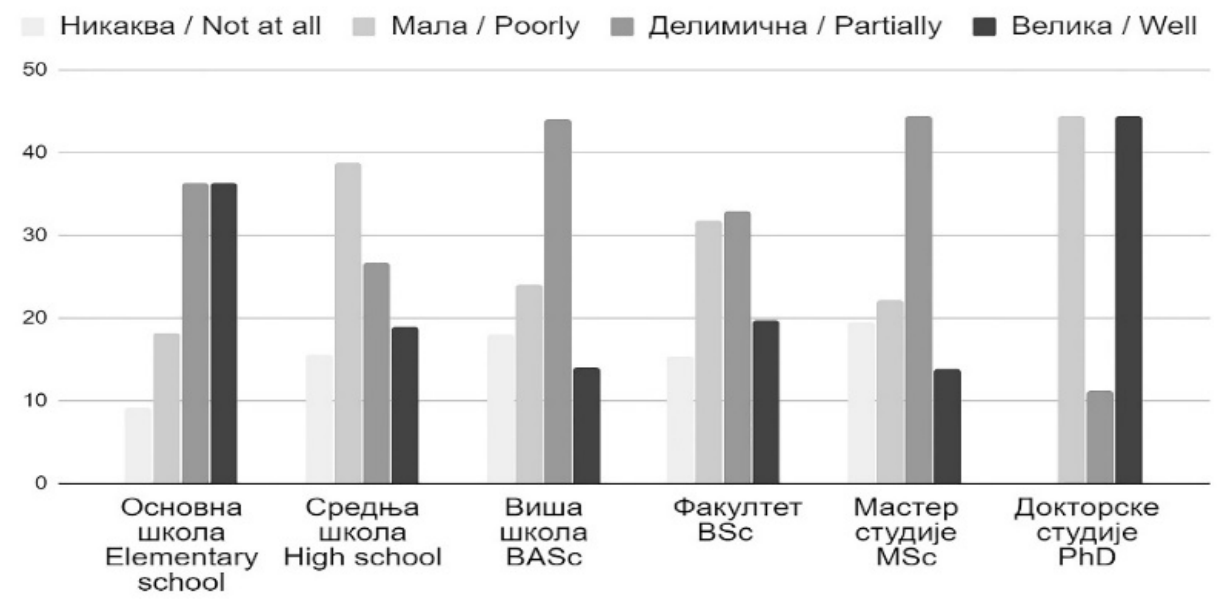

Figure 3. Attitudes of the local population about the tourist potentials of SNR "Deliblato Sands" in relation to the acquired education

As a source of information about SNR "Deliblato Sands", 38.6\% of respondents use the Internet, 30.1\% are informed through relatives and friends, $16.2 \%$ by visiting the site and obtaining information from the guides, and the lowest percentage $(0.9 \%)$ is informed in travel agencies. About $14 \%$ of respondents in this question chose the option "other" and wrote the following answers related to sources of information: television shows, spatial plans, scientific papers, official documents, experiences of other people, professional literature about Deliblato Sands, NGO, mountaineering activities, photographs, employment in companies in the area of Deliblato Sands, participation in interregional projects, 
ownership of a cottage or house on the territory of SNR "Deliblato Sands" and a personal visit to it without a guide service. In these answers, respondents also pointed out that they did not find any unified information about Deliblato Sands unless they had searched for it via the Internet. Also, dissatisfaction was noticed in the Deliblato settlement due to contaminated springs, unpleasant odors caused by the farms and inadequate work of the Tourism Organization of the municipality of Kovin. These data indicate an inadequately designed promotion of the nature reserve, mostly relied on the Internet, which is inaccessible or invisible to many residents. Also, the promotional activities of tourism organizations and travel agencies should be improved, because they are the least used source of information about the SNR "Deliblato Sands". Intensifying the promotion of protected areas through tourism organizations and agencies could also increase the number of tourists visiting them.

As the greatest potential for tourism development in the SNR "Deliblato Sands", the inhabitants of South Banat consider natural - geological, geomorphological, hydrological values $(49.9 \%)$ and rich flora and fauna $(41 \%)$. This is the evidence that more than $90 \%$ of respondents recognized the value and importance of biodiversity and natural landscapes, which can serve as a base for creating tourism offer. Respondents who chose the option "other" in this question, wrote different opinions about the most significant tourism potentials in this area. They think that natural values, wildlife and gastronomy should be combined into an integral offer, space cleaning and waste removal should be carried out, that greatest potential is in the specific climate of the protected area and endemic species as well as in the positioning of Deliblato Sands as a destination with healthy air, important for treating respiratory problems. Some respondents suggested including sightseeing of the reserve from the air balloons, introducing electric bus tours, "safari" offers, waste cleaning in the reserve and surrounding areas and constructing several accommodation facilities in local architectural style, from natural materials, which will fit into the environment. Owing to these facts, it is evident that the local population is aware of the importance of preserving and valorizing natural values for tourism, has ideas on how to contribute to the protection of this area and wants to direct further tourism development towards the ecological features.

The largest percentage of respondents recognized SNR "Deliblato Sands" as an area with the greatest potential for ecotourism development, SNR "Kraljevac" with medium, and LOF "Karaš- Nera" with the low potential for ecotourism development. When evaluating the existing ecotourism offer in these destinations (hiking, bird watching, sport fishing, educational lectures, photo safari, plant collection and recognition, cycling, sports activities), most respondents believe that the offer of ecotourism activities is weak in all three destinations. However, it is necessary to emphasize that when evaluating the ecotourism offer in SNR 
"Deliblato Sands", opinions are divided. About 32\% of respondents think that the offer is poor, about $28 \%$ that it is average, and $27 \%$ consider the offer excellent. On the other side, only $13 \%$ of respondents think that the ecotourism offer in SNR "Kraljevac" and LOF "Karas-Nera" is excellent. Further research should determine whether such data are a consequence of the actual situation and inadequate offer or just insufficient information about it. Also, it should be examined whether SNR "Deliblato Sands" is better rated because of the superior tourist offer or because of more available information comparing to the other two protected areas.

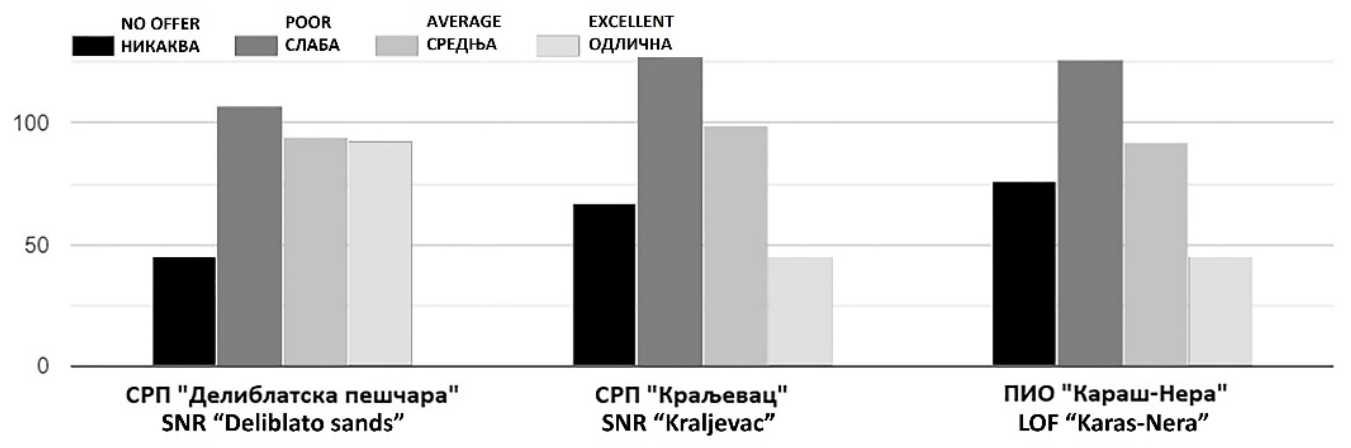

Figure 4. Evaluation of the existing ecotourism offer

Confirmation of the opinion that natural values are the greatest potential for tourism development is the fact that $98.8 \%$ of respondents agree with the statement: "Deliblato Sands has significant natural potentials for tourism development." However, $93.8 \%$ of respondents consider that they are not used enough. They believe $(91.4 \%)$ that the development of ecotourism would contribute to the protection and preservation of Deliblato Sands. This attitude implies a high awareness of the positive effects of ecotourism on the natural environment. It is important to emphasize that more than half of the respondents $(56 \%)$ have already done specific activities in order to preserve and protect this area. Their practical actions are a direct indicator of interest in improving the environment. Considering the distribution of respondents who have already contributed to the protection of this area, it can be concluded that the largest share (about 48\%) of those who have not taken any measures to protect and preserve natural values of SNR " Deliblato Sands" is in Vrsac, while the share of those who contributed to the preservation of this area is the largest in Bela Crkva (about 63\%), and in Kovin (about 61\%). This can be related to the fact that the largest number of settlements located on the territory of SNR "Deliblato Sands" belong to the municipalities of Kovin and Bela Crkva. 


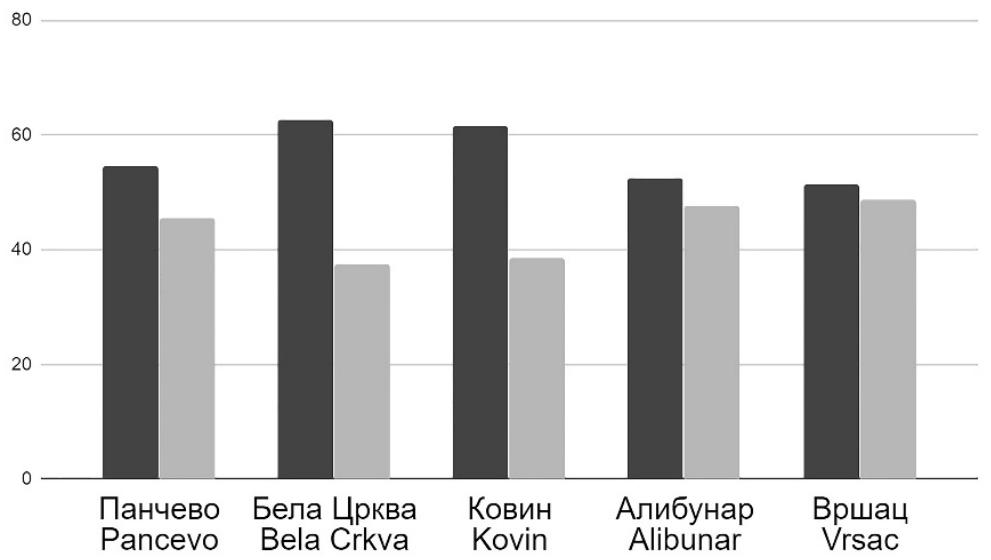

Figure 5. Previous contribution to the protection and preservation of Deliblato Sands according to the municipalities

When it comes to anticipating the economic benefits of ecotourism, the responses were mostly uniform. Respondents (96.5\%) believe that ecotourism development in the SNR "Deliblato Sands" would contribute to the economic empowerment of South Banat municipalities and the creation of new jobs, as well as to the improvement of quality of life (93.2\%). About $78 \%$ of respondents believe that ecotourism would reduce the emigration of young people from South Banat municipalities, which may be related to the generation of new employment opportunities in the tourism sector.

About two-thirds of the respondents believe that they would personally benefit from the development of ecotourism, and $71.4 \%$ of the respondents believe that they can personally contribute to its development. This data is important because it indicates that the majority of respondents think that change is coming from an individual and that everyone can contribute to the ecotourism development of the SNR "Deliblato Sands". Also, the possibility of achieving personal benefits from ecotourism can be a strong motivator for community involvement in the development process. This is supported by the fact that $77 \%$ of respondents expressed a desire for direct participation in activities necessary for the development of ecotourism, which reflects their proactive attitude. It is interesting to emphasize that a higher percentage of those interested in direct involvement in ecotourism development are women (about $57 \%$ of all who are interested), which can be related to the increased opportunities that tourism creates for employment and prosperity of the female population. Also, respondents without income, with income up to $200 €$ and income from $200 €$ to $500 €$ represent 
together $67 \%$ of respondents who are interested in involvement in ecotourism development. This implies that the population with income lower than $500 €$ shows a greater interest in the development of ecotourism because it provides them the opportunity to earn additional revenue.

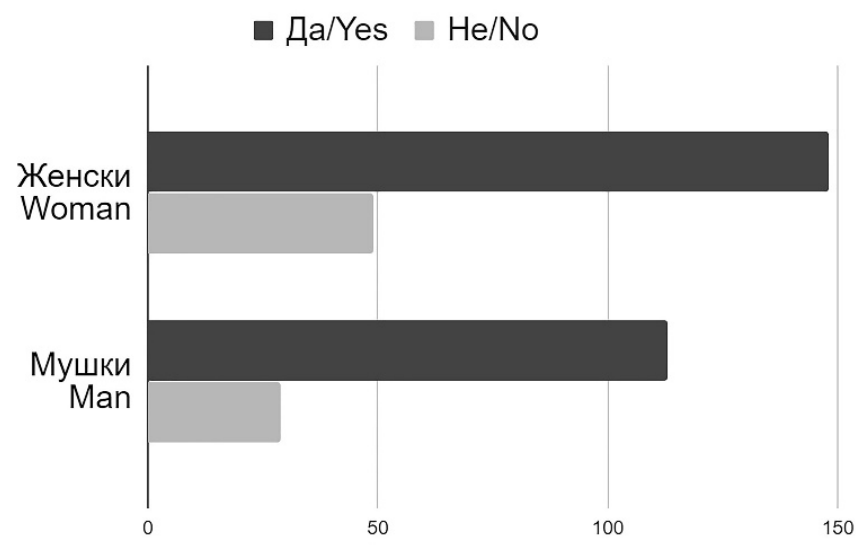

Figure 6. Willingness for direct participation in the development of ecotourism according to the gender of the respondents

It is also important to note that $97.6 \%$ of respondents would like to know more about the ecotourism potentials of this area. By improving the presentation of natural and complementary values, more residents could become interested in direct contribution to development. The fact that $93.8 \%$ of the respondents expressed a desire to see a larger number of tourists visiting Deliblato Sands in the future is an evidence for the enthusiasm of local residents about the improvement of tourism in this area.

\section{Conclusion}

SNR "Deliblato Sands" is an area that has a significant potential for ecotourism development thanks to its specific morphological attributes, rich biodiversity, the presence of rare and endangered species and exceptional landscape features.

This research determined that the inhabitants of South Banat municipalities have a positive attitude towards the development of ecotourism in the area of SNR "Deliblato Sands". Half of them have already done activities that contribute to its protection (especially residents of Bela Crkva and Kovin), and they are proactive in their approach to further ecotourism development of this area. 
Moreover, some respondents suggested innovative activities for future ecotourism offer, that match with the principles of sustainable development. Differences in the distribution of responses concerning gender and monthly income were observed in the assessment of readiness for direct participation in ecotourism development. Women and people with lower income showed greater interest in inclusion in ecotourism development, which may be associated with perceiving tourism as an opportunity for additional revenue. Intensifying the participation of the local community in planning the further tourism development of SNR "Deliblato Sands" could contribute to the enrichment of the tourist offer, directing the tourism development, controlling its effects by the local population and strengthening the local economy.

SNR "Deliblato Sands" is recognized as an area with the greater ecotourism potential comparing to SNR "Kraljevac" and LOF "Karas-Nera". But, general information about the development opportunities of all three protected areas is low, existing ecotourism offer is perceived as scarce and weak, and potentials as underutilized. In the further period, the focus should be on the education of the local population related to the natural values of these areas and the possibilities of their valorization for tourism purposes, as well as on intensifying promotional activities that will make the offer of protected areas more visible to potential visitors. Due to the proximity of these three protected areas and the similarity of their geographical and ecological features, an integrated tourist offer should be formed. Moreover, ecotourism should be presented as one of the priority development forms and a stronghold for strengthening the image of South Banat as an ecotourism destination of exceptional natural values.

The limitation of this research is reflected in the uneven distribution of respondents from the five considered municipalities. As a consequence of that, the obtained results mostly refer to the residents of Pancevo, Kovin and Alibunar. Therefore, it is recommended for further research to ensure equal representation of respondents from Pancevo, Kovin, Alibunar, Bela Crkva and Vrsac, in order to obtain more complete results. It would be important to include the managers of protected areas in the research and examine their attitudes towards the development of ecotourism because they could be one of the implementers of tourist activities in these areas.

\section{References}

Бранков, J. (2010). Еколошки туризам у заштићеним објектима природе у Банату. Београд: Географски институт „Јован Цвијић“, САНУ. 
Belij, M., Đurđić, S. \& Stojković, S. (2018). The Evaluation of Geoheritage for Geotourism Development: Case Study on the Potential Geopark Djerdap. Collection of Papers - Faculty of Geography at the University of Belgrade, 66(2), 121132. doi: $10.5937 /$ zrgfub1802121B

Brankov, J., Jovičić D., \& Milijašević D. (2015). Sustainable Tourism in National Park "Đerdap", Serbia - Attitudes of Local Population. Journal of the Geographical Institute Jovan Cvijic, SASA, 65(2), 183-199. doi: 10.2298/IJGI1502183B

Bubalo-Živković, M., Lukić, T., Đerčan, B., Stojsavljević, R., Bjelajac, D. \& Ristanović, B. (2018). Thermal mineral waters of Vojvodina (Serbia) and the possibility of their use: A case study of the Municipality of Kikinda. Collection of Papers - Faculty of Geography at the University of Belgrade, 66(1), 53-70. doi: 10.5937/zrgfub1866053B

Ceballos-Lascura' in, H. (1987). The future of ecotourism. Mexico Journal January, 13 -14.

Diamantis, D. (2010). The Concept of Ecotourism: Evolution and Trends. Current Issues in Tourism, 2(2), 93-122.

Đurđić, S. (2017). Potentials and constraints of ecotoursim development in Serbia, In: Filipović, D., Gosar, A., Koderman, M., Đurđić, S. (eds.) Tourism in protected areas of nature in Serbia and Slovenia, University of Belgrade - Faculty of Geography, 57-72.

Đurđić, S., Stojković, S. \& Belij, M. (2019). The importance of ecotourism in the process of improving ecosystem services in Serbia. In Proceedings of the International Scientific Symposium New Trends in Geography, 3 - 4 October 2019, Ohrid, Republic of North Macedonia, Macedonian Geographical Society, pp. 123-132, ISBN 978-608-65155-6-0; UDC: 338.48-6:502/504(497.11)

Fennell, A. D. (2015). Ecotourism (4 ${ }^{\text {th }}$ ed.). London: Routledge.

Ghazali, S. \& Sirat, M. (2011). Global ecotourism and local communities in rural areas. Penang: Penerbit Universiti Sains Malaysia.

Jovanović, L., Živković, D., Janković, M., Šiljak, V. \& Toskić, D. (2019). Significance of sustainable eco-tourism for Serbia's economic development. Collection of Papers - Faculty of Geography at the University of Belgrade, 67(2), 53-67. doi: 10.5937/ zrgfub1902053J

Ковачев, Н., Ромелић, J., Пивац, Т., и Лукић, Т. (2014). Излети као примарни и пратећи облици других туристичких кретања у Делиблатској пешчари. Зборник радова Департмана за географију, туризам и хотелијерство, 43(2), 137155.

Krejić, Ž., \& Plećić, K. (2014). Options the Deliblato Sand for the Development of Specific Forms of Tourism. HORIZONS, 13, 317-324.

Menković, Lj. (2013). Eolian relief of Southeast Banatian. Bulletin of The Serbian Geographical Society, 93(4), 1-22.

Nunkoo, R., \& Ramkissoon, H. (2011). Developing a community support model for tourism. Annals of Tourism Research, 38(3), 964-988. doi: 10.1016/j. annals.2011.01.017 
Nunkoo, R., Ramkissoon, H., \& Gursoy, D. (2013). Use of structural equation modeling in tourism research: Past, present, and future. Journal of Travel Research, 52(6), 759-771. doi:10.1177/0047287513478503

Nunkoo, R., \& So, K. (2015). Residents' Support for tourism: Testing alternative structural models. Journal of Travel Research. doi:10.1177/0047287515592972

Pajvančić, A., \& Markov, S. (2011). The role of the local populace in the development of ecotourism: The views of residents of Vojvodina cities on the Danube. Zbornik Matice Srpske za Društvene Nauke, 134, 51-67. doi: 10.2298/ZMSDN1134051P

Пантелић, М., Стаменковић, И., и Пурић-Самарџија, J. (2012). Развој екотуризма на простору Специјалног резервата природе "Делиблатска пешчара“. Зборник радова Департмана за географију, туризам и хотелијерство, 41, 235-247.

Petrović, K., (2014). Zaštita tekunice: Stanišne potrebe, rasprostranjenost i stanje populacije u Specijalnom rezervatu prirode "Kraljevac". Preuzeto sa: http://srpkraljevac.rs/ wp-content/uploads/2015/10/Izvestaj-tekunica-SRP-Kraljevac.pdf

Петровић, Н. и Шкрбић, Б. (2016). Еколошке вредносне оријентације и спремност на активизам у Србији. Зборник радова - Географски факултет Универзитета у Београду, 64, 47-71. doi: 10.5937/ zrgfub1664047P

Покрајински секретаријат за урбанизам и заштиту животне средине (2019). Просторни план подруија посебне намене Предела изузетних одлика „Караш Нера“: Наирт просторног плана. Нови Сад: Покрајински секретаријат за урбанизам и заштиту животне средине.

Pokrajinski zavod za zaštitu prirode (n.d.). SRP „Deliblatska peščara“. Preuzeto sa: http://www.pzzp.rs/rs/sr/zastita-prirode/zasticena-podrucja/specijalnirezervati-prirode-srp.html

Sedlak, M. (2019). Afforestation as a factor of physically geographical changing: A case study of Deliblato sand. Collection of Papers - Faculty of Geography at the University of Belgrade, 67(1), 45-59. doi: 10.5937/zrgfub1901045S

Sharpley, R. (2014). Host perceptions of tourism: A review of the research. Tourism Management, 42, 37-49. doi: 10.1016/j.tourman.2013.10.007

Trišić, I. (2019). Opportunities for sustainable tourism development and nature conservation in Special Nature Reserve "Deliblatska Peščara". Hotel and Tourism Management, 7(1), 83-93. doi: 10.5937/menhottur1901083T

Udruženje sportskih ribolovaca „Deliblatsko jezero" (2015). Specijalni rezervat prirode "Kraljevac" - Istorijat. Preuzeto sa: http://srpkraljevac.rs/sr/istorijat/

Vujko, A., Petrović, M.D., Gostović, D., Radovanović, M., \& Vuković, D. (2018). The Role of Natural Resources in the Ecotourism Development - Residents' Perceptions in Subotica (Northern Serbia). The Central European Journal of Regional Development and Tourism, 10(2), 112-123. 